\title{
Optimization of conditions for the induction of Tagetes patula L. hairy roots
}

\author{
L.P. Khlebova* , E.S. Brovko, O.V. Bychkova, N.V. Pavlova
}

\author{
Altai State University, \\ Barnaul, Russia, E-mail: hlebova61@mail.ru
}

Received: 10.08.2019. Accepted: 25.10.2019

\begin{abstract}
The hairy root cultures are promising sources of secondary metabolites of plants, including rare and endangered species. They possess genetic and biochemical stability, unlimited growth rate in free-hormone medium, short doubling times, high biosynthetic activity and ecological purity of plant raw materials. The hairy root cultures of Tagetes patula L. can be used to produce biologically active substances with biocidal activity. The study aimed to determine the virulent strain of Agrobacterium rhizogenes and the most effective period of co-cultivation of $T$. patula leaf explants with an agrobacterium to induce actively growing hairy root cultures. We used 3 strains (A-4b, 8196RT and 15834). The time of infection ranged from 3 to 33 hours in increments of 3 hours. We found that $24 \mathrm{~h}$ is the best time of infection to induce hairy roots with the highest transformation efficiency (92\%). The wild strain $A$. rhizogenes 15834 turned out to be the most virulent when infected leaf explants of spreading marigold. This strain provided the maximum transformation effect, reaching $85.4 \%$. We have identified 5 actively growing clones of hairy roots with intensive branching, the growth indices of which were 64-75. In the future, they will be transferred to a liquid medium for biomass accumulation and scaling.
\end{abstract}

Keywords: Tagetes patula; Leaf explants; Agrobacterium rhizogenes, Hairy root culture

\section{Introduction}

One of the most promising areas of modern phytobiotechnology is the use of cell cultures of higher plants to obtain biologically active substances for medicine, veterinary medicine, perfumery, agriculture, food and chemical industries (Dicosmo and Misawa, 1995; Ramachandra Rao and Ravishankar, 2002; Mulabagal and Tsay, 2004; Malik et al., 2011; Orlova et al., 2014; Isah et al., 2018; Kochkin et al., 2019; Watcharatanon et al., 2019). The validity of this approach is determined, on the one hand, by the evergrowing demand for natural compounds that are unique in structure and activity, and on the other hand, by the extremely low level of natural resources of producers, many of which are rare and endangered plant species (Verpoorte, 2002; Nosov, 2012). In addition, the relative simplicity in the extraction of the metabolites from in vitro-produced tissues makes the method suitable for commercial application (Kolewe et al., 2008; Gonçalves and Romano, 2018). One of the sources of secondary metabolites is the hairy roots culture, the growth of which is initiated by the transfer of the Rol gene of the soil bacterium Agrobacterium rhizogenes to the plant cell genome (Bensaddek et al., 2008; Ono and Tian, 2011; Vladimirov et al., 2015; Dhiman et al., 2018). The root culture obtained in this way has genetic and biochemical stability, unlimited growth rate in growth regulator-free media, short doubling times, high biosynthetic activity and responsiveness to elicitor treatments as well as ecological purity of the plant raw materials (Vdovichenko et al., 2007; Kuzovkina and Vdovichenko, 2011; Khan et al., 2018; Halder et al., 2019). Over the past decades, there was a lot of data on the development of effective protocols for inducing hairy root cultures that can synthesize biologically active substances (Giri et al., 2001; Saleh and Thuc, 2009; Saravanakumar et al., 2012; Farag and Kayser, 2015; Belabbassi et al., 2016; Patra and Srivastava, 2016).

The genus Tagetes belongs to the family Asteraceae and is used as an ornamental plant (Marotti et al., 2004). However, the chemicals that make up the plants determine the usefulness of representatives of this genus (marigolds) as sources of various classes of secondary metabolites that are used in the pharmaceutical and food industries (Giri et al., 2011; Chkhikvishvili et al., 2016). In addition, these substances can also be used as the main component of agents with biocidal activity (Mares et al, 2004; Mulabagal and Tsay, 2004; Faizi et al., 2011; Politi et al., 2016; Ayub et al., 2017; Krzyzaniak et al., 2017; Mir et al., 2019). For example, marigolds are known to be a source of thiophenes, which are a group of heterocyclic sulfur compounds, the most common of which is a-Tertienyl (Ketel, 1986). Thiophenes have allelopathic, insecticidal, nematicidal, antifungal, bactericidal and cytotoxic effects (Talov et al., 1994; Rajasekaran et al., 1999, 2004; Taha et al., 2013). The bioactive substances of natural origin are known to have some advantages, since they are obtained from renewable resources, and the selection of resistant forms occurs at a slower rate than with synthetic insecticides. Also, they show low or no toxicity to mammals and bees (Ghosh et al., 2012). It was revealed that the remains of the marigold plants prevented the germination of the seeds of some weeds, thereby determining the potential of thiophenes as natural weed control agents (Batish et al., 2007). Moreover, it was found that the number of nematodes in the soil decreased when some crops were grown using root extracts of plants of the genus Tagetes (Siddiqui et al., 1987). When studying the effect of the hexane extract of tricyclic thiophenes produced from genetically transformed roots of $T$. patula L., a high larvicidal activity on mosquito larvae of several species was noted (Rajasekaran et al., 2004). In addition, a-Tertienyl has a short half-life in the environment, which is 4 hours, not showing cross-resistance to other pesticides due to the new mode of action (Hasspieler et al., 1988). A culture of genetically transformed marigold roots can be an alternative source of thiophene-rich raw materials (Kyo et al., 1990; Buitelaar et al., 1991; Rajasekaran et al., 1999, 2004; Ramachandra Rao et al., 2001). A comparative analysis in different 
phases of the growth of hairy root culture showed that the total thiophene content in most hairy root lines was almost 4 times higher than in wild-type roots (Gupta et al., 2016). The aim of this work was the induction in in vitro of rapidly growing lines of hairy root cultures of $T$. patula for their further use in the production of biologically active substances with biocidal activity.

\section{Materials and Methods}

To obtain aseptic plants, T. patula seeds were thoroughly washed in a soap solution and placed under running water for 15 minutes. Sterilization was carried out with $70 \%$ ethyl alcohol for 2 minutes, followed by disinfection in lysoformine-3000 for 15 minutes. After washing 3-4 times with sterile distilled water, the seeds were transferred into glass flasks on the agarized Murashige and Skoog (MS) base medium (Murashige \& Skoog, 1962) with a sucrose concentration of $30 \mathrm{~g} \mathrm{I}^{-1}$, supplemented with $4 \mu \mathrm{M}$ gibberellic acid. The seedlings were grown in a ICH 750LMemmert climatic chamber at a temperature of $24 \pm 0.3{ }^{\circ} \mathrm{C}$ and under $16-$ $\mathrm{h}$ light/8-h dark photoperiod. The collection of $A$. rhizogenes strains was maintained on an agarized YEB medium at a temperature of $+4 \pm 0.3^{\circ} \mathrm{C}$, followed by transfer to fresh medium once every 3 weeks. For the genetic transformation of spreading marigold explants, we used the protocol that we developed earlier (Bychkova et al., 2018). First of all, fresh cultures of agrobacteria of 3 strains were prepared. These were A-4b, 8196RT and 15834 (from the collection of K.A. Timiryazev Institute of Plant Physiology of the Russian Academy of Sciences, Moscow). Bacteria were cultured on YEB medium for 24 hours at a temperature of $28 \pm 1{ }^{\circ} \mathrm{C}$ in the dark. Flushing of the bacterial culture was used for its joint cultivation with explants.

After the seedlings reached 10 days of age, we carried out an agrobacterial transformation by co-cultivating an overnight culture of agrobacteria and $T$. patula leaf explants damaged by a sterile needle. Flasks with plant explants and a suspension of agrobacteria were placed on a rotary shaker with a speed of $90 \mathrm{rpm}$ at $26 \pm 1{ }^{\circ} \mathrm{C}$. Time intervals for co-cultivation of leaf explants and agrobacteria were evaluated by observing 10 periods. The time of contacting bacteria with explants ranged from 3 to 33 hours in increments of 3 hours. In this experiment, agrobacterial transformation was carried out by strain 15834 . Further cultivation of transformed explants was done as follows. The suspension was filtered, the explants were washed with liquid MS medium and transferred to Petri dishes on a semi-solid hormone-free MS base medium with a sucrose concentration of $25 \mathrm{~g} \mathrm{I}^{-1}$. To exclude further bacterial growth, the antibiotic Klaforan $\left(500 \mathrm{mg} \mathrm{l}^{-1}\right)$ was added to the nutrient medium, the concentration of which subsequently decreased with each passage to 250, 125, and $60 \mathrm{mg} \mathrm{l}^{-1}$ (Mikhailova et al., 2017; Bychkova et al., 2018). Then we carried out the transformation of the explants with the three strains indicated above. The period of joint cultivation of leaf segments and bacteria in a liquid medium was 24 hours.

The root induction frequency was calculated by the ratio of the number of initiated root lines to the number of explants passaged onto the semi-solid medium (\%). To assess the growth of root culture, the length of primary roots, as well as the number of secondary and tertiary roots, were determined. The growth activity of the cultures was evaluated by the growth index (GI), which was calculated by the difference in the length of the roots at the end and beginning of the passage using the formula:

where $I_{0}$ is the initial root length; $I_{1}$ is the final length of the roots.

$$
\mathrm{GI}=\mathrm{I}_{1}-\mathrm{I}_{0} / \mathrm{I}_{0} \text {, }
$$

The experiment was performed in 5 replicates, 10 explants per replicate. The Least Significant Differences $\left(\mathrm{LSD}_{0.05}\right)$ were used to assess the reliability of the differences among the mean values.

\section{Results and Discussion}

Artificial induction of hairy roots in plants is technically relatively uncomplicated. Despite this, not all plants can quickly be infected with $A$. rhizogenes. There are so-called "difficult" species for which it is necessary to resort to certain "tricks", including selection of the type and age of the plant tissue, the presence or absence of explant wounding, the density of the bacterial suspension, strain genotype, infection technique, the duration of the period of co-cultivation of the explants and bacteria (Park and Facchini, 2000; Bensaddeket al., 2008; Saleh and Thuc, 2009; Sharada et al, 2015). The explants most commonly used for infection are young tissues of sterile seedlings. We infected aseptic young leaves of 10 day old seedlings, having previously injured them with a sterile needle. The duration of the plant - bacterium contact during the inoculation and the co-cultivation is known to be parameter that can be optimized. According to various sources, the duration of co-cultivation can range from several hours to several days (Vdovichenko et al., 2007; Wahyuni et al., 2017). We evaluated the effects of 10 periods of incubation of explants in suspension of strain 15834 on induction of a primary hairy root culture. The effectiveness of agrobacterial transformation of marigold leaf explants depending on the time of their co-cultivation with strain 15834 is shown in Figure 1.

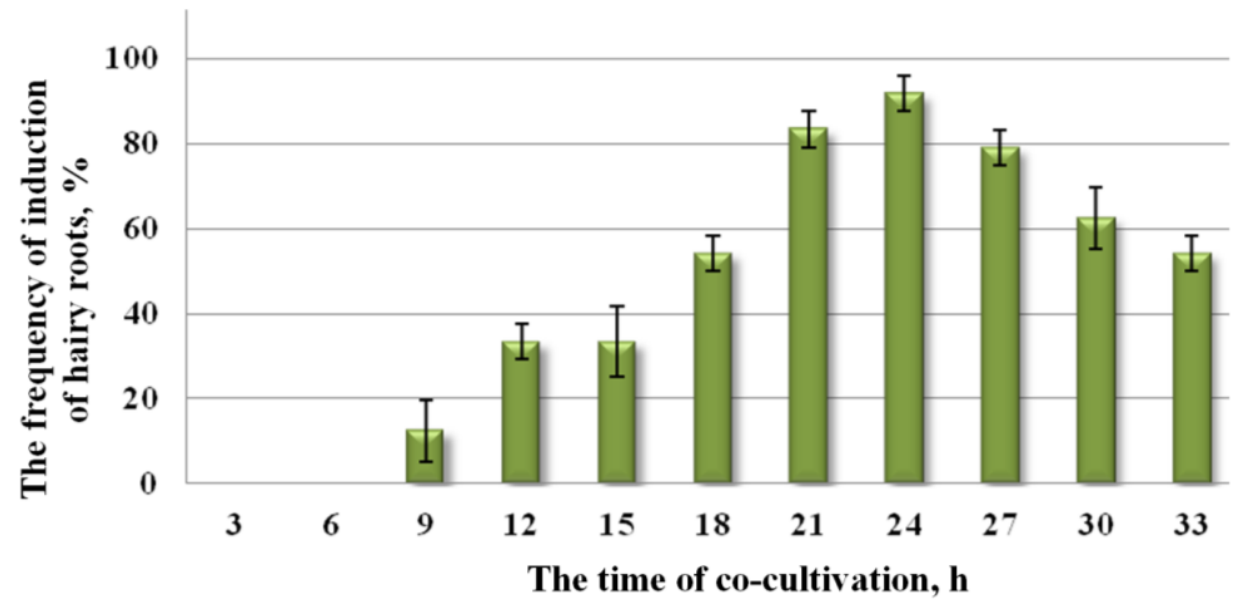

Figure 1. Frequency of induction of hairy roots depending on the time of co-cultivation of leaf explants of Tagetes patula L. with Agrobacterium rhizogenes strain $15834\left(\mathrm{LSD}_{0,05}=6.2\right)$. 
After the transformation and transfer of leaf explants into Petri dishes to the semi-solid medium MS, primary roots appeared after 45 days of incubation. The proportion of explants that form roots ranged from 0 to $91.7 \pm 4.2 \%$ depending on the time of their joint cultivation with agrobacteria. A single root formation was observed after co-cultivation for 9 hours, which was about $12.5 \pm 7.2 \%$. The maximum induction of hairy roots was observed at 21 and 24 hours of co-cultivation, reaching $83.3 \pm 4.1$ and $91.7 \pm 4.2 \%$, respectively. A longer incubation of leaf explants with the agrobacterial strain did not lead to an increase of rhizogenesis, but, on the contrary, a decrease in the trait was observed. At 27-30 hours, the level of rhizogenesis was 79-62.5\%. After explants were incubated in a bacterial suspension for 18 hours, their further cultivation on a semi-solid medium led to the formation of callus in $12 \%$ of cases. According to Kuzovkina and Vdovichenko (2011), callus formation quite often precedes root formation on explants. Thus, the co-cultivation of leaf explants of spreading marigold with a bacterial suspension of strain 15834 provided the maximum effect by contacting for 24 hours.

Infection of explants with a more virulent strain can significantly increase the efficiency of transformation. Therefore, for more successful infection, it is necessary to use different strains of soil agrobacteria (Giri et al., 2001; Saleh and Thuc, 2009; Lee et al., 2010). Also, if the goal of the experiment is to obtain a hairy root culture as an alternative raw material for medicine or the food industry, then it is necessary to use only wild strains. In this case, the further applying the cultures obtained with the participation of genetically modified strains can be problematic (Kuzovkina and Vdovichenko, 2011). Having determined the optimal incubation time, we carried out the transformation of explants with three strains of agrobacteria (A-4b, 8196RT and 15834). The frequency of transformation varied significantly depending on a strain genotype (Figure 2).

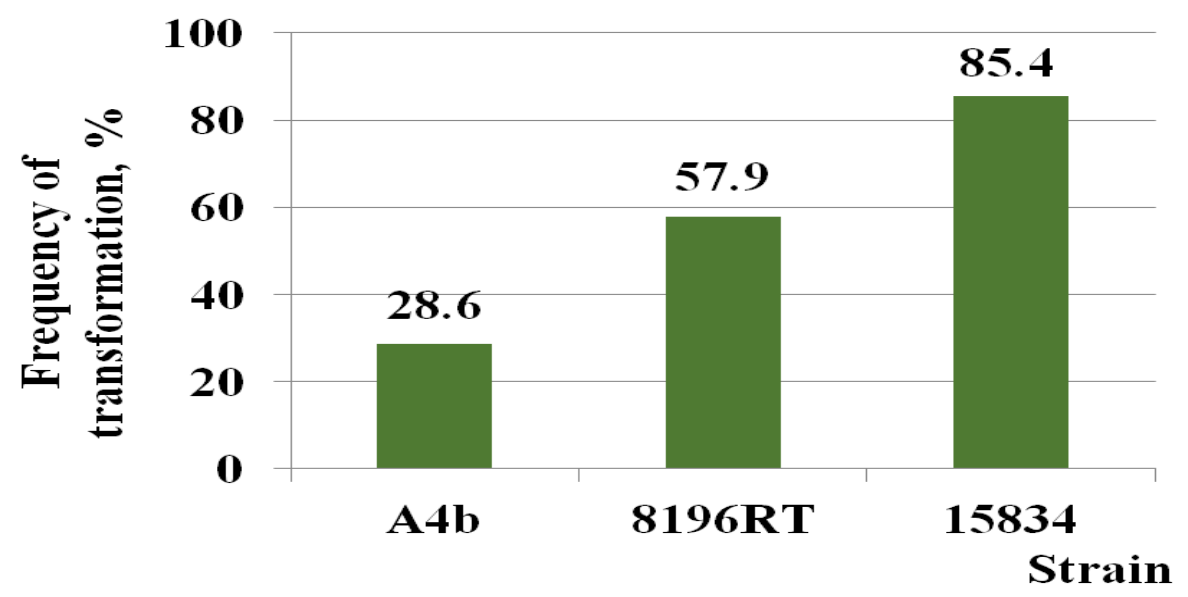

Figure 2. In vitro transformation of leaf explants of Tagetes patula L. by various strains of Agrobacterium rhizogenes $\left(\mathrm{LSD}_{0,05}=\right.$ 7.8).

Maximum success was observed using the wild strain $15834(85.4 \pm 6.1 \%)$. The modified A4b strain appeared to be less aggressive, the effectiveness of which was 3 times lower. Strain 8196RT showed an intermediate virulence, providing a level of transformation in the range of $57.9 \pm 5.6 \%$. It should be noted the different nature of the effects of strains on $T$. patula leaf explants. So 15834 caused mainly multiple rhizogenesis, and A4b, on the contrary, provided single rhizogenesis. A specific feature of the action of strain 8196RT was the induction of callusogenic processes which inhibited the formation of root cultures (Figure 3).

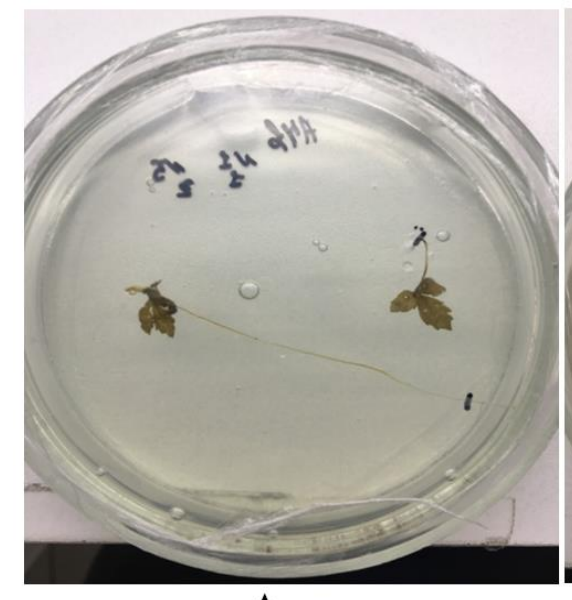

A

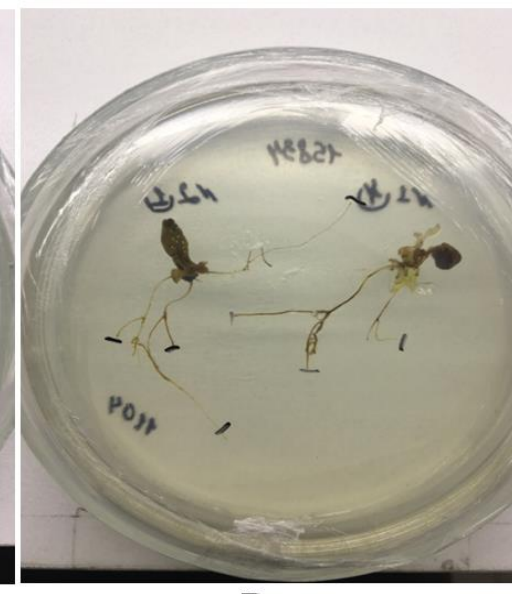

B

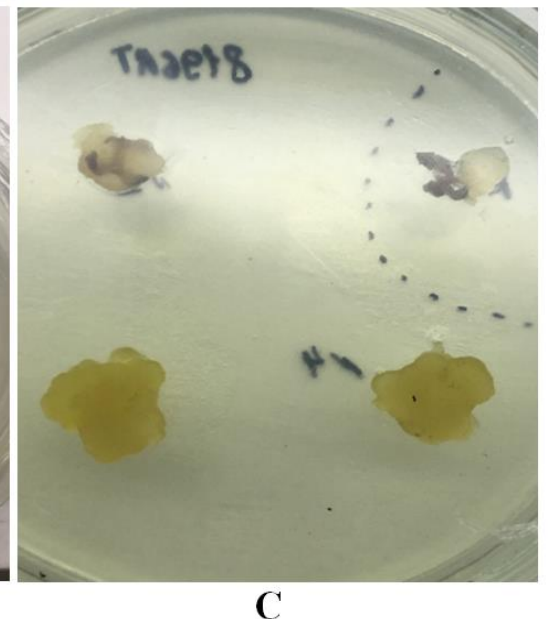

C

Figure 3. Different types of induction processes during transformation of Tagetes patula L. explants by various strains of Agrobacterium rhizogenes: A - Single root induction (A4b); B - Induction of several roots (15834); C - Callus induction (8196RT).

It is known that roots obtained in vitro culture have certain morphological characters, the assessment of which suggests that they are most likely genetically transformed (Kuzovkina \& Vdovichenko, 2011; Kuluev el al., 2015). The hairy roots induced in our study grew well on hormone-free media, branching intensively, and had plagiotropic growth. When assessing the growth activity of individual root lines, we found that they significantly differed from each other both in the growth rate and in the type of branching. After 3 weeks, some of them formed a composition characteristic of genetically transformed roots, while other lines slowed down 
growth or the growth rate was not significant (Figure 4). In total, more than 50 lines were isolated; the characteristics of the best of them are presented in Table 1.

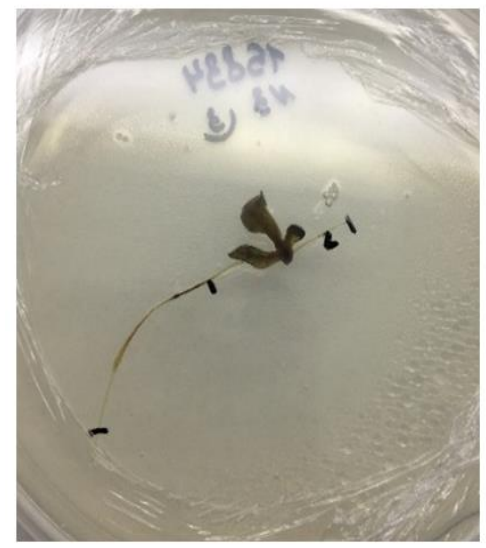

A

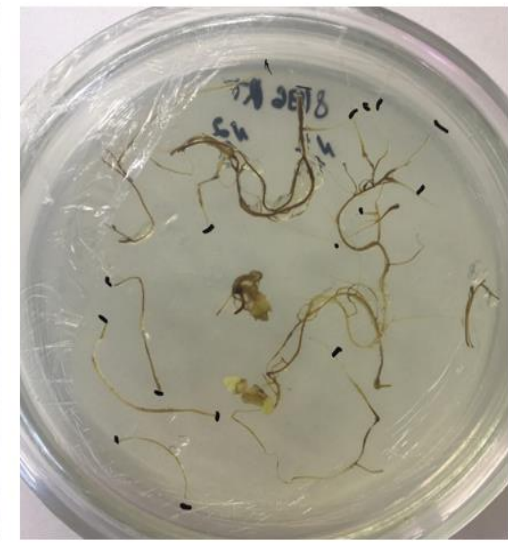

B

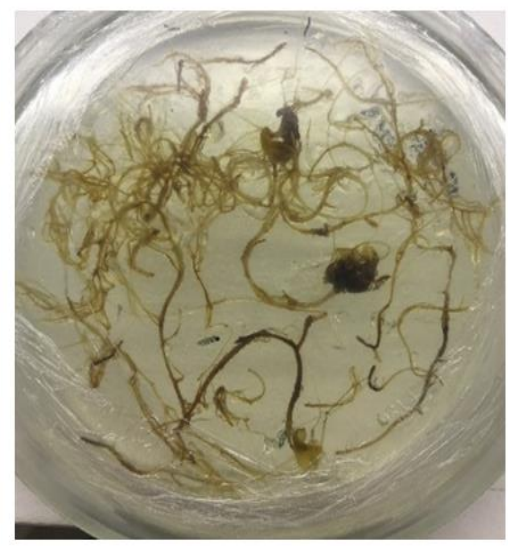

C

Figure 4. Various models of growth and branching of Tagetes patula L. genetically transformed roots :

A - Slowly growing, non-branching roots; B - Weakly branching roots; C - Fast-growing, well-branching roots.

The main indicator of the effectiveness of an agrobacterial strain is the growth rate of the formed roots, characterized by a growth index. The maximum values were shown by clones initiated by strain 15834 , whose growth indices reached 75 -fold values. The root growth rate induced by strains 8196RT and A4b was inferior to the lines described above. Assessments of growth of root cultures also included the length of the primary roots, as well as the number of secondary and tertiary roots. The greatest length of the primary roots was observed in the lines obtained as a result of transformation by strain 15834 . The same lines were distinguished by intensive branching, as evidenced by the number of lateral roots of the second and third orders, which form the main increase in root biomass. The root cultures obtained by transformation with strain A-4b had the lowest values of the length of primary roots and a relatively small number of secondary and tertiary roots.

Table 1. Growth characteristics of Tagetes patula L. hairy root lines.

\begin{tabular}{lllll}
\hline Hairy root line & Growth index & $\begin{array}{l}\text { Length of primary } \\
\text { roots, } \mathbf{~ c m}\end{array}$ & $\begin{array}{l}\text { Number of } \\
\text { secondary roots, } \\
\text { pcs. }\end{array}$ & $\begin{array}{l}\text { Number of tertiary } \\
\text { roots, pcs. }\end{array}$ \\
1-15834 & 75 & 15.2 & 28 & $>50$ \\
$2-15834$ & 69 & 13.6 & 26 & $>50$ \\
$3-15834$ & 68 & 13.2 & 19 & $>40$ \\
4-8196RT & 63 & 11.3 & 12 & $>40$ \\
5-8196RT & 64 & 11.0 & 11 & 32 \\
6-8196RT & 47 & 9.6 & 11 & 26 \\
7-A4b & 54 & 12.5 & 9 & 19 \\
8-A4b & 39 & 9.1 & 9 & 21 \\
9-A4b & 42 & 9.1 & 12 & 24 \\
\hline
\end{tabular}

\section{Conclusion}

The co-cultivation of leaf explants of spreading marigold ( $T$. patula) with a bacterial suspension of strain 15834 provided the maximum effect by contacting for 24 hours. The wild strain $A$. rhizogenes 15834 turned out to be the most virulent when infected marigold leaf explants. This strain provided the maximum transformation effect, reaching $85.4 \%$. We have identified 5 actively growing clones with intensive branching, the growth indices of which were 64-75. In the future, they will be transferred to a liquid medium for biomass accumulation and scaling.

\section{Conflict of Interest}

The authors declare that they have no conflict of interests.

\section{References}

Ayub, M. A., Hussain, A. I., Hanif, M. A. et al. (2017). Variation in phenolic profile, b-carotene and flavonoid contents, biological activities of two Tagetes species from Pakistani flora. Chemistry Biodiversity, 14.

Batish, D. R., Arora, K., Singh, H. P., \& Kohli, R. K. (2007). Potential utilization of dried powder of Tagetes minuta as a natural herbicide for managing rice weeds. Crop Protect, 26, 566-571.

Belabbassi, O., Khelifi-Slaoui, M., Zaoui, D., Benyammi, R., Khalfallah, N., Malik, S., Makhzoum, A., \& Khelifi, L. (2016). Synergistic effects of polyploidization and elicitation on biomass and hyoscyamine content in hairy roots of Datura stramonium. Biotechnologie, Agronomie, Société et Environnement, 20, 408-416.

Bensaddek, L., Villarrea, M. L., \& Fliniaux, M. A. (2008). Induction and growth of hairy roots for the production of medicinal compounds. Electronic Journal of Integrative Biosciences 3, 1, 2-9.

Buitelaar, R. M., Langenhoff, A. A. M., Heidstra R., \& Tramper J. (1991). Growth and thiophene production by hairy root cultures of Tagetes patula in various twoliquid phase bioreactors. Enzyme microbiology and biotechnology, 13, 487-494. 
Bychkova, O. V., Khlebova, L. P., Brovko, E. S., \& Borsukova, A. I. (2018). Efficient induction of hairy roots in Tagetes patula L. Ukrainian Journal of Ecology, 8(4), 450-453.

Chkhikvishvili, I., Sanikidze, T., Gogia N. et al., (2016). Constituents of French Marigold (Tagetes patula L.) Flowers protect jurkat Tcells against oxidative stress. Oxidative Medicine and Cellular Longevity, 2016, Article ID 4216285.

Dhiman, N., Patial, V., \& Bhattacharya, A. (2018). The current status and future applications of hairy root cultures. In: Kumar N. (ed) Biotechnological Approaches for Medicinal and Aromatic Plants. Springer, Singapore.

Dicosmo, F., \& Misawa, M. (1995). Plant cell and tissue culture: Alternatives for metabolite production. Biotechnology Advances, 13, 425-453.

Faizi, S., Fayyaz, S., Bano S. et al. (2011). Isolation of nematicidal compounds from Tagetes patula L. yellow flowers: Structureactivity relationship studies against cyst nematode Heterodera zeae infective stage larvae. Journal of Agricultural and Food Chemistry, 59(17), 9080-9093.

Farag, S., \& Kayser, O. (2015). Cannabinoids production by hairy root cultures of Cannabis sativa L. American Journal of Plant Sciences, 6, 1874-1884. http://dx.doi.org/10.4236/ajps.2015.611188

Ghosh, A., Chowdhury, N., \& Chandra, G. (2012). Plant extracts as potential mosquito larvicides. Indian Journal of Medical Research, 135, 5, 581-598.

Giri, A. A, Ravindra, S. T., Dhingra, V. T, \& Narasu, M. L. (2001). Influence of different strains of Agrobacterium rhizogenes on induction of hairy root and artemisinin production in Artemisia annua. Curr. Sci., 81, 378-382.

Giri, R. K., Bose, A., \& Mishra, S. K. (2011). Hepatoprotective Activity of Tagetes erecta against Carbon Tetrachloride-Induced Hepatic Damage in Rats. Acta Poloniae Pharmceutica-Drug Research, 68, 999-1003.

Gonçalves, S., \& Romano, A. (2018). Production of plant secondary metabolites by using biotechnological tools. In: Secondary Metabolites - Sources and Applications; Vijayakumar, R., Raja, S. S.S., Eds.; InTech. DOI: 10.5772/intechopen.76414.

Gupta, V., Shanker, K., \& Rahman, L. (2016). In vitro production of thiophenes using hairy root cultures of Tagetes erecta (L.). African Journal of Biotechnology, 15(17), 706-713.

Halder, M., Sarkar, S., \& Jha, S. (2019). Elicitation: A biotechnological tool for enhanced production of secondary metabolites in hairy root cultures. Eng Life Sci, 1-16. https://doi.org/10.1002/elsc.201900058

Hasspieler, B. M., Arnason, J. T., \& Downe, A. E. (1988). Toxicity, localization and elimination of the phototoxin, a-terthienyl in mosquito larvae. J Am Mosq Control Assoc, 4(4), 479-484.

Isah, T., Umar, S., Mujib, A., Sharma, M. P., Rajasekharan, P. E., Zafar, N., \& Frukh, A. (2018). Secondary metabolism of pharmaceuticals in the plant in vitro cultures: Strategies, approaches, and limitations to achieving higher yield. Plant Cell Tissue and Organ Culture, 132, 239-265. DOI: 10.1007/s11240-017-1332-2

Ketel, D. (1986) Morphological differentiation and occurrence of thiophene in leaf callus cultures from Tagetes sp. The effect of growth medium of the plants. Acta Physiol Plantarum, 66, 392. DOI: 10.1111/j.1399-3054.1986.tb05940.x

Khan, S., Siddiqui, M., \& Osama, K. (2018). Bioreactors for Hairy Roots Culture: A Review. Current Biotechnology, 7(6), 417-427.

Kochkin, D. V., Globa, E. B., Demidova, E. V., Gaisinsky, V. V, Kuznetsov, V. V., \& Nosov, A. M. (2019). Detection of taxuyunnanin C in suspension cell culture of Taxus canadensis. Doklady Akademii Nauk, 485, 3, 374-376. DOI:10.31857/S0869-56524853374-376

Kolewe, M. E., Gaurav, V., \& Roberts, S. C. (2008). Pharmaceutical active natural product synthesis and supply via plant cell culture technology. Molecular Pharmaceutics, 5, 243-256. DOI:10.1021/mp7001494

Krzyzaniak, L. M., Antonelli-Ushirobira, T. M., Panizzon, G., Sereia, A. L., de-Souza, J. R. P., Zequi, J. A. C., Novello, C. R., Lopes, G. C., de Medeiros, D. C., Silva, D. B., Leite-Mello, E. V. D., \& De-Mello, J. C. P. (2017) Larvicidal Activity against Aedes aegypti and chemical characterization of the inflorescences of Tagetes patula. Evidence-Based Complementary and Alternative Medicine, 1-8. https://doi.org/10.1155/2017/9602368

Kuluev, B. R., Vershinin, Z. R., Knyazev, A. V., Chemeris, D. A., Baymiev, An. H., Chumakov, M. I., Baymiev, K., \& Chemeris, A.V. (2015) «Kosmatye» korni rastenui - vazhnyi instrymentariy dlya issledovateley i moshchnaya fitohim-biofabrika dlya proizvodstvennikov. Biomeka, 2, 70-120. (In Russian)

Kuzovkina, I. N., \& Vdovichenko, M. Yu. (2011). Geneticheski transformirovannye korni kak model izychenia fiziologicheskih i biohimicheskih processov kornevoi systemy cselogo rastenia. Plant physiology, 58 (5), 787-796. (In Russian)

Kyo, M., Miyauchi, Y., Fujimoto, T., \& Mayama, S. (1990). Production of nematocidal compounds by hairy root cultures of Tagetes patula L. Plant Cell Reports, 9, 393-397.

Lee, S. Y, Kim, S. G., Song, W. S., Kim, Y. K., Park, N. I., \& Park, S. U. (2010). Influence of different strains of Agrobacterium rhizogenes on hairy root induction and production of alizarin and purpurin in Rubia akane Nakai. Romanian Biotechnological Letter, $15,5405-5409$.

Malik, S., Rosa, M., \& Cusido B. (2011). Production of the anticancer drug taxol in Taxus baccata suspension cultures. Process Biochemistry, 46, 23-34.

Mares, D., Tosi, B., Poli, F., Andreotti, E., \& Romagnoli, C. (2004) Antifungal activity of Tagetes patula extracts on some phytopathogenic fungi: ultrastructural evidence on Pythium ultimum. Microbiol Res, 159, 295-304.

Marotti, M., Piccaglia, R., Biavati, B., \& Marotti, I. (2004) Characterization and yield evaluation of essential oils from different Tagetes species. Journal of Essential Oil Research, 16, 440-444.

Mikhailova, E. V., Kuluev, B. R., Sibaeva, G. R., \& Chemeris A.V. (2017). Sozdanie kul'tur borodatyh korney Withania somnifera i otcenka parametrov ih rosta pri vyrashchivanii na tverdyh i zhidkih pitatel'nyh sredah. Bulletin of physico-chemical biology and biotechnology. Ovchinnikov, 13(2), 40-45. (In Russian)

Mir, R. A., Ahanger, M. A., \& Agarwal, R. M. (2019). Marigold: From mandap to medicine and from ornamentation to remediation. American Journal of Plant Sciences, 10, 309-338. https://doi.org/10.4236/ajps.2019.102024

Mulabagal, V., \& Tsay, H. (2004) Plant cell cultures as a source for the production of biologically important secondary metabolites. Int J Appl Sci Engin, 2, 29-48.

Murashige, T., \& Skoog, F. A. (1962). Revised medium for rapid growth and boassays with tobacco tissue cultures. Physiol. Plant, $15,473-497$.

Nosov, A. M. (2012). Application of cell technologies for production of plant derived bioactive substances of plant origin. Applied Biochemistry and Microbiology, 48, 7, 609-624.

Ono, N. N., \& Tian, L. (2011). The multiplicity of hairy root cultures: prolific possibilities. Plant Sci., 180(3), 439-446. doi: 10.1016/j.plantsci.2010.11.012 
Orlova, L. V., Globa, E. B., Chernyak, N. D., Demidova, E. V., Titova, M. V., Solovchenko, A. E., Sergeev, R. V., \& Nosov, A. M. (2014). Growth and bioartificial characteristics of Taxus baccata suspension culture (cultivation in flasks and bioreactor). Vestnik of Volga State University of Technology. Ser.: Forest. Ecology. Nature Management, 3(23), 86-97. (In Russian)

Park, S-U, \& Facchini, P. J. (2000). Agrobacterium rhizogenes-mediated transformation of opium poppy, Papaver somniferum L., and California poppy, Eschscholzia californica Cham., root cultures. J Exp Bot, 347, 1005-1016.

Patra, N., Srivastava, A. K. (2016). Artemisinin production by plant hairy root cultures in gas- and liquid-phase bioreactors. Plant Cell Rep, 35(1), 143-153. doi: 10.1007/s00299-015-1875-9.

Politi, F. A. S., Queiroz-Fernandes, G. M., Rodrigues, E. R., Freitas, J. A., \& Pietro, R. C. L. R. (2016). Antifungal, antiradical and cytotoxic activities of extractives obtained from Tagetes patula L. (Asteraceae), a potential acaricide plant species. Microbial Pathogenesis, 95, 15-20.

Rajasekaran, T., Madhusudhan, R., \& Ravishankar, G. A. (1999). Elicitation of thiophene production by cultured hairy roots of Tagetes patula. Acta Physiol. Plant, 21, 243-247.

Rajasekaran, T., Ravishankar, G. A., \& Obul Reddy, B. (2004). In vitro growth of Tagetes patula L. hairy roots, production of thiophenes and its mosquito larvicidal activity. Indian Journal of Biotechnology, 3, 92-96.

Ramachandra Rao S., \& Ravishankar. G. A. (2002) Plant cell cultures: Chemical factories of secondary metabolites. Biotechnol Advances, 20, 1-53.

Ramachandra Rao, S., Tripathi, U., Suresh B., \& Ravishankar G. A. (2001). Enhancement of secondary metabolite production in hairy root cultures of Beta vulgaris and Tagetes patula under the influence of microalgal elicit. Food biotechnology, 15(1), 35-46. DOI: $10.1081 /$ FBT-100103893

Saleh, N. M. \& Thuc, L. V. (2009). Assessment of hairy roots induction in Solenostemon scutellarioides leaves by different strains of Agrobacterium rhizogenes. African Journal of Biotechnology, 8(15), 3519-3523.

Saravanakumar, A., Aslam, A., \& Shajahan, A. (2012). Development and optimization of hairy root culture systems in Withania somnifera (L.) Dunal for withaferin-A production. African Journal of Biotechnology, 11(98), 16412-16420.

Siddiqui, M. A., \& Alam, M. M. (1987). Utilization of marigold plant wastes for the control of plant parasitic nematodes. Biol Wastes, 21, 221-229.

Taha, H. S., Osman, H. A., Youssef, M. M. A., El-Gindi, A.M.Y., Ameen, H. H., \& Lashein, A. M. S. (2013). Chromatographic analysis of thiophenes in calli and suspension cultures of Tagetes spp. Journal of Life Sciences, 7(5), 483-490.

Talov, R. J., Cascone, O., \& Giulietti, A. M. (1994). Content of thiophenes in transformed root cultures of Argentinian species of Tagetes. Planta-Medica, 60(3), 260-262.

Vdovichenko, M. Yu., Kuzovkina, I. N., Pitts, H., \& Schneider, B. (2007) Kyltiviruemye in vitro korni kopeechnika chainogo i obrazovanie $v$ nih fenol'nyh soedineniy. Plant physiology, 54 (4), 604-613. (In Russian)

Verpoorte, R., Contin, A., \& Memelink, J. (2002). Biotechnology for the production of plant secondary metabolites. Phytochem. Rev., $1,13-25$.

Vladimirov, I. A., Matveeva, T. V., \& Lutova, L. A. (2015). Opine biosynthesis and catabolism genes of Agrobacterium tumefaciens and Agrobacterium rhizogenes. Russian Journal of Genetics, 51(2), 121-129.

Wahyuni, D. K., Wahyuni, S., Ermayanti, T. M., Wardoyo, B. E., Purnobasuki, H., \& Utami, E. W. (2017). Various infection time of Agrobacterium rhizogenes strain LB510 for hairy root induction on Justicia gendarussa Burm.f. International Journal of ChemTech Research, 10(4), 404-411.

Watcharatanona, K., Ingkaninanc, K., \& Putaluna, W. (2019). Improved triterpenoid saponin glycosides accumulation in in vitro culture of Bacopa monnieri (L.) Wettst with precursor feeding and LED light exposure. Industrial Crops \& Products, 134, $303-308$. https://doi.org/10.1016/j.indcrop.2019.04.011

Weaver, D. K., Zettler, L. J., Wells, C. D., Baker J. E., Bertsch, W., \& Throne, J. E. (1997) Toxicity of fractionated and degraded Mexican marigold floral extract to adult Sithophilus zeamais (Coleopteran : Curculionidae). Journal of Economic Entomology, 90, 1678-1683.

\section{Citation:}

Khlebova, L.P., Brovko, E.S., Bychkova, O.V., Pavlova, N.V. (2019). Optimization of conditions for the induction of Tagetes patula L. hairy roots Ukrainian Journal of Ecology, 9(3), 415-420.

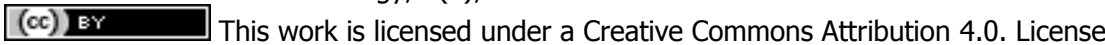

